\title{
THE EFFECT OF WORK LIFE QUALITY, WORK CULTURE, WORK MOTIVATION, AND RELIGIUSITY ON STAFFS PERFORMANCE
}

\author{
Nury Yasien Rachmatullah ${ }^{1}$ \\ Muhaimin Dimyati \\ Zainollah $^{3}$ \\ High School of Economics of Mandala \\ Email: yasinidonx15@gmail.com
}

\begin{abstract}
This empirical investigation aimed to determine the effect of work life quality, work culture, work motivation, and religiusity on the staffs performance in SD Al BaitulAmien (full day school) Jember. Population of this study was all tachers in SD Al BaitulAmien (full day school) Jember totaling 20 persons used for the sample. Data were collected with a questionnaire using a Likert scale. Then they were analyzed using correlation and regression techniques using Statistical Package For Social Science (SPSS) program version 23.0.The study found that : 1) Quality of working life (QWL) has a positive effect on the performance of staffs in the SD Al BaitulAmien (full day school) Jember. 2) the work motivation has a positive effect on the staffs performance in the SD Al BaitulAmien (full day school) Jember.3) Work culture has positive effect on staff performance in SD Al BaitulAmien (full day school) Jember. 4) Religiosity have a positive effect on staff performance in SD Al BaitulAmien (full day school) Jember. The findings of this study provide practical advice to staffs and principals to be able to enhance SD Al BaitulAmien (full day school) Jember. Quality of working life, work culture, motivation and religiosity in order to optimize the performance of staff increased at SD Al BaitulAmien (full day school) Jember.
\end{abstract}

Keywords : Quality of Working Life, Work Culture, Work Motivation, Religousity.

\section{INTRODUCTION}

Work environment is a place of employees in work that is not less important in improving the performance of employees. Therefore, the organization must provide adequate working environment such as physical environment including comfortable office spaces, clean environment, good air exchange, color, adequate lighting and good music. Nonphysical environment includes the work atmosphere of employees, employee welfare, relationships among employees, relationships between employees with leaders, and places of worship. A good working environment can support the implementation of work so that employees have the spirit of work and improve employee performance (Sedarmayanti, 2001:31).

Quality of work life is a concept or philosophy of management in order to improve the quality of human resources that have been known since the decade of the seventies. At that time the quality of work life is narrowly defined as a management technique that includes a quality control 
group, employment benefits, an approach to negotiate with unions, management efforts to maintain the mental fitness of employees, participatory management and one form of intervention in organizational development (French et al, 1990 dalam Noor Arifin, 1999).The quality of working life is a major issue that deserves organizational attention (Lewis et al., 2001). This refers to the idea that the quality of work life is seen as capable of increasing the participation and contribution of members or employees to the organization. Previous research has shown that the quality of working life has a positive and significant impact on performance (May and Lau, 1999). The quality of working life also fosters the desire of teachers and employees to remain in the organization. Research also shows a positive relationship between the quality of work practices and the performance of teachers and employees ( Elmuti dan Kathawala, 1997 )

Work culture has a very strategic role to encourage and improve the performance of the organization in general, and in particular the performance of employees working in an organization, both in the short and long term. The role of work culture is as a tool for determining the direction of the organization, directing what employees can and should not do, how to allocate and manage organizational resources, as well as a tool for dealing with the problems and opportunities of the organizational environment.

Every activity undertaken by a person is driven by an inner strength, this driving force is what is called motivation. Motivation is a complex problem in the organization, because the needs and desires of each member of the organization are different. This is different because every member of the organization is a biological and psychological unit and develops on the basis of different learning processes (Sugiyono,2011).

Sedarmayanti (2007: 233) defines motivation as a willingness to expend high levels of effort toward organizational goals conditioned by the ability of the effort to meet individual needs. Robbins (2008: 222) also suggests the definition of motivation as a process that explains the intensity, direction, and perseverance of an individual to achieve his goal.

Religiusity is a form of human relationship with its creator through the teachings of religion that has been internalized in a person and is reflected in his attitude and everyday behavior. Ahmad (in Subaidi 2013). A person who holds his belief will be automatically reflected in the daily association. If in his belief the belief states that work is worship, then an employee will earnestly and rejoice in welcoming his daily duties and work. Religiosity can be manifested in all sides of human life. Religious activity is not only happening when a person performs a ritual act, but also when performing other activities that are driven by supernatural powers. Not only that which is related to visible activity, but also the activity that is not visible and occurs in one's heart. Thus religion is a dimensionless system. Religion in the sense of Glock \& Stark is a system of symbols, systems of beliefs, value systems and behavioral systems that are institutionalized and centered on issues that live as the ultimate meaning.

Al Baitul Amien Elementary School (Full Day School) is a private Islamic elementary school that applying a combination of general and Islamic learning packed in an integrated curriculum and has a strong vision of printing good charachter students and optimal achievement. SD Al Baitul Amien established since 1997 and located in the city center that is in the town square of Jember, currently experiencing a fairly rapid development. This is evidenced by the growing interest of prospective new students who register and even register indent for the following years. With the number of students as many as $\mathbf{5 7 8}$ students are divided into 16 classes, of course require teachers and employees are appropriate to further improve the service quality is more optimal. Currently SD Al 
Baitul Amien has number of teachers as many as 48 people and employees of 20 people. In addition to the board of teachers, employees also have an important role besides the teacher and always improve its performance so that school vision and mission can be achieved well.

Performance is a manifestation of work done by employees who usually used as a basis assessment of employees or organizations. A good worker is a step towards achieving the goals of the organization (Hariman and Gilbert 1982: 324 in Yulianti, 2006). Therefore performance is the decisive means of achieving organizational goals, so that it is needed to improve performance. But this is not easy, because many factors affect a person's high performance.

Conceptual Framework

The following conceptual framework illustrates a significant influence between quality of work life, work culture, motivation and religiosity have a positive influence on employee performance. Based on the description, the relationship of influence between variables in this study as a whole is depicted.

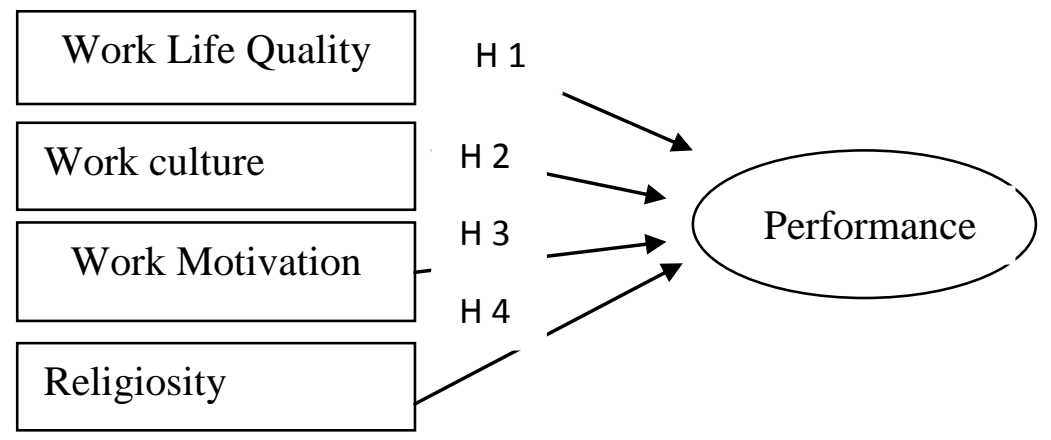

Figure 1: Conceptual Framework

\section{RESEARCH METHODS}

This research will be conducted at $\mathrm{Al}$ Baitul Amien Elementary School (Full Day School) Jember. Type of research used in this research is explanatory research. Explanatory research is an explanatory research in which this study highlights the relationship between independent variables on the dependent variable and tests the hypotheses that have been formulated previously Singarimbun in Amin (2017).

The population of this study is all employees of Al Baitul Amien Elementary School (Full Day School) Jember 20162017 as many as 20 employees.

\section{Operational Definition of Variables}

1. Quality of Work Life (X1)There are two views on the purpose of quality of work life. First view is said that the quality of working life is a number of circumstances and practices of organizational goals (for example: workplace prosperity, democratic supervision, worker involvement and comfortable working conditions). While the other view holds that the quality of working life is the perceptions of employees that they want to feel secure, relatively contented and have the opportunity to grow and develop as human beings (Cascio, 1991).There are eight indicators in the quality of work life measurements developed by Walton (in Zin 2004) but in this study only four indicators are used: a. Growth and development, b. Participation, c. innovative rewards system, d. Work environment

2. Working Culture (X2)

Work culture is a philosophy based on the view of life as values that become the nature, habits and driving forces, entrenched in the life of a community group or organization, then reflected from the attitude to be behavior, beliefs, 
ideals, opinions and actions that manifest as "work" or "work" (Triguno, 1995: 3).

The employment culture indicators are as follows: a. Physical environmental conditions of work, including: awarding, giving welfare, fulfilled infrastructure and facilities. b. Environmental conditions of work, including: support in performing tasks, able to design work, supervision and discipline of work, communication and interaction with peers, parents, principals and community environment, principal leadership functions, set personnel policies, according to the nature and purpose, establishing the compensation policy and school management.

3. Work Motivation (X3)

Motivation is the provision of a stimulus or encouragement to improve employee morale to work in accordance with the desired by the leadership through the instructions in an effort to achieve the goal. Employee motivation will be determined by the motivator. Motivator that is intended is a motivator engine labor so that the effect of individual workforce workers influence. The motivating elements are (Martoyo, 2002): Achievement, Appreciation, Challenged, Responsible, Development, Involvement, and Chance

4. Religiosity (X4)

Religiosity as a state that exists within a person behaves, acts and in accordance with the teachings of religion he embraces. Religiosity (diversity) is manifested in all sides of human life. This needs to be distinguished from religion because religious connotations usually refer to institutional moves in the aspect and personalization of the institution. According to Ahmad (2012), the indicator of religiosity is the aspect of charity. The indicators used are as follows: looking for a halal sustenance, do justice, honest, do not commit a disgraceful act, and respect others.

\section{Performance}

Employee performance can be interpreted as work performance or work (output) both quality and quantity achieved by employees per period in carrying out their duties in accordance with the responsibilities given to him. Performance is the work achieved by a person or group of persons within an organization, in accordance with their respective powers and responsibilities in an effort to achieve the objectives of the organization in a legal, unlawful, moral and ethical manner (Prawirosentono, 2005: 76). Gomes (2000) in Mangkunegara (2009: 42) presents several types of employee performance criteria as follows:

a. Quantity Of Work, ie the amount of work earned within a specified time period.

b. Qualitiy Of Work, ie the quality of work achieved based on the terms and conformity.

c. Job Knowledge, which is the breadth of knowledge about work and skills.

d. Creativeness, which is the originality of ideas raised and actions to solve the problems that arise.

e. Cooperative, ie willingness to cooperate with others.

f. Dependability, ie awareness and trustworthiness in terms of attendance and work completion.

g. Initiative, ie the spirit to carry out new tasks and in enlarging its responsibilities.

h. Personal Quality, ie awareness and trustworthiness in terms of hospitality.

\section{RESULTS ANALYSIS}

Validity test in this research use construct validity, that is tested by correlating each item statement with total score for each variable. The validity criterion performed by factor analysis (Confimatory Factor Analysis) is valid if KMO value> 0.5 and Barlett's Test with significance $<0,05$ (Ghozali, 2002: 47). 
Table 1: Test Results Reliability

Reliability Statistics

\begin{tabular}{|c|c|c|}
\hline $\begin{array}{c}\text { Cronbach's } \\
\text { Alpha }\end{array}$ & $\begin{array}{c}\text { Cronbach's } \\
\text { Alpha Based on } \\
\text { Standardized } \\
\text { Items }\end{array}$ & N of Items \\
\hline 0,748 & 0,952 & 41 \\
\hline
\end{tabular}

Based on the above table can be seen that the results of reliability testing for all variables indicate that the value of alpha cronbach greater than 0.70 so it can be concluded that the questionnaire used to measure the quality of work life, work culture, motivation, religiosity and performance is reliable. The questionnaire used is a very reliable because it can provide results that are not different if it is done on the same subject at different times.
Normality testing is performed on residual regression. Tests using the P-P chart Plot. The normal data is the data that make up the spreading dots not far from the diagonal. The result of linear regression analysis with normal graph of P-P Plot to residual error of regression model obtained has shown the existence of normal graph pattern, that is the spreading point which is not far from diagonal line. Normality test results are presented in Figure 2.

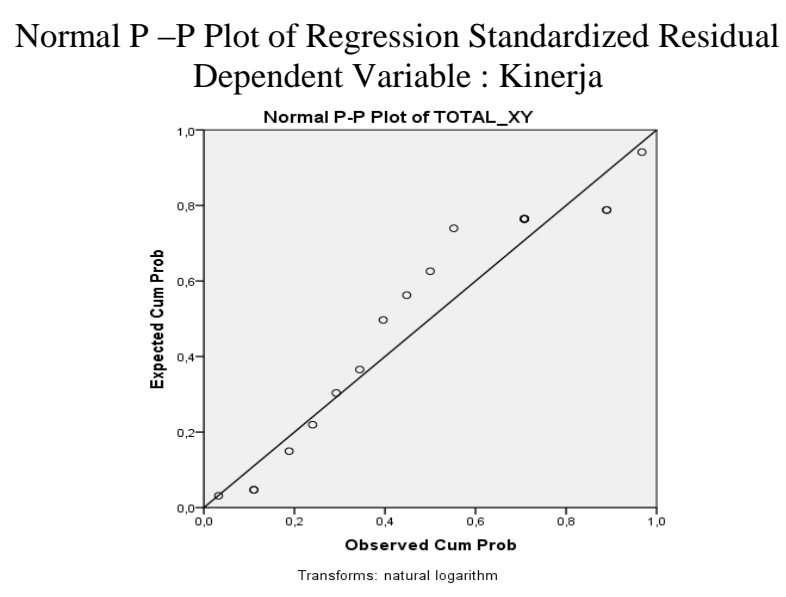

Figure 2: Test Result Normality

Based on the picture above can be seen that the normal graph probability plot the points spread around the diagonal line and its distribution follows the direction of the diagonal line, so it can be concluded that the regression model is feasible to use because it meets the assumption of normality.

The multicollinearity test in this study is to look at SPSS output in table coefficient if the VIF (variance inflation factor) value below 10 (VIF <10) or tolerance value greater than 0.10 means not to be multicollinearity. This test shows that all the variables used as predictors of the regression model show a fairly small VIF value, all of which are below 10 and tolerance values greater than 0.1 . This means that the independent variables used in this study do not show any symptoms of multicollinearity, so all the independent variables in this study are independent variables, so it can be continued in multiple linear tests.

\section{INTERPRETATION}

Multiple regression analysis is used by the researcher, if the researcher intends to predict how the condition (ups and downs) of the dependent variable, if two or more independent variables as predictor factor is manipulated (lowered nil value). So multiple regression analysis will be done 
when the number of independent variables at least two (Sugiyono, 2012). From the results of multiple linear regression equation can be explained as follows:

a. Constant value of 2.945 indicates that the quality of work life is not good, work culture is not good, motivation is less and religiosity is not good then its performance will not good or decrease.

b. Coefficient of variable of quality of work life equal to 0,057 mean every perception of quality of work life increase, hence will improve performance, and vice versa if perception of quality of work life decrease, hence will degrade performance.

c. Coefficient of motivation variable equal to 0,065 means every perception of work culture increase, hence will improve performance, and vice versa if cultural perception of work decrease, hence will degrade performance.

d. Coefficient of variable quality of work life of 0.652 contains the meaning of each perception of work motivation increases, it will improve performance, and vice versa if the perception of work motivation decreases, it will degrade performance.

e. The coefficient of religiosity variable of 0.125 implies that every perception of quality of work life increases, it will improve performance, and conversely if the perception of religiosity decreases, it will decrease performance. The coefficient of determination $\left(\mathrm{R}^{\wedge} 2\right)$ is intended to determine the best level of accuracy in the regression analysis. This is shown by the magnitude of the determination coefficient $\left(\mathrm{R}^{\wedge} 2\right)$ between 0 (zero) to 1 (one). To see the coefficient of determination on multiple linear regression is to use the value of $R$ Square. From the coefficient of determination $\left(\mathrm{R}^{\wedge} 2\right)$ it can be obtained a value to measure the contribution of several variables $X$ to the variation up and down $\mathrm{Y}$ variable that is usually expressed in percentage. Based on the research can be known coefficient of determination $\left(\mathrm{R}^{\wedge} 2\right)$ is equal to 0,900 . This means that $90.00 \%$ performance can be explained by the quality of work life, work culture, motivation and religiosity. While the remaining $10.00 \%$ performance is influenced by other variables that are not examined in this study such as commitment, job satisfaction, and so forth.

In general, this study shows the result that the condition of respondents' assessment of these research variables in general has been good. This can be shown from the number of responders' high responses to the condition of each research variable. From these results, it was found that four independent variables, namely quality of work life, work culture, work motivation and religiosity have influence on performance. The result of the research shows that motivation is very significant simultaneously and partially to the performance of $\mathrm{Al}$ Baitul Amien elementary school (full day school) Jember. This research is in line with Koesmono (2005) research which proves that motivation has significant effect both simultaneously, partially and dominantly.

Quality of Work Life, Work Culture, Motivation and Religiosity simultaneously significantly influence the performance of employees at Al Baitul Amien Elementary School (full day school) Jember. These results support the first hypothesis that the quality of work life, work culture, motivation and religiosity simultaneously and partially have a significant effect on performance. This means that the perception of Al Baitul Amien elementary school (full day school) Jember about the quality of work life, work culture, motivation and religiosity increases, it will improve the performance of $\mathrm{Al}$ Baitul Amien elementary school (Jember) and vice versa if the perception of SD Al Baitul Amien (full day school) Jember about the quality of working life decreases, it will decrease the performance of $\mathrm{Al}$ Baitul Amien elementary school (full day school) 
Jember. This finding means that the quality of working life has been able to improve the high performance.

Quality of work life, work culture, and religiosity partially no significant effect on employee performance in Al Baitul Amien Elementary School (full day school) Jember. While the motivation partially significantly affect the performance of employees at Al Baitul Amien Elementary School (full day school) Jember. This result does not support the second hypothesis that the quality of work life, work culture, motivation and religiosity are partially significant to performance. This means that if the perception of $\mathrm{Al}$ Baitul Amien elementary school (full day school) Jember about the quality of working life, work culture, motivation and religiosity increases, it will improve the performance of Al BaitulAmien elementary school (Jember) and vice versa if the perception of Al SD Baitul Amien (full day school) Jember about the quality of working life decreases, it will decrease the performance of Al Baitul Amien elementary school (full day school) Jember. This finding means that the quality of working life has been able to improve high performance.

Motivation dominantly affect the performance of $\mathrm{Al}$ Baitul Amien elementary school (full day school) Jember. This does not support the third hypothesis which states that the quality of work life has a dominant effect on performance.

\section{CONCLUSION}

Based on the result of analysis and interpretation it can be concluded as follows, Quality of Work Life, Work Culture, Motivation and Religiosity simultaneously significantly influence the performance of employees at Al Baitul Amien Elementary School (full day school) Jember. Quality of work life, work culture, and religiosity partially no significant effect on employee performance in $\mathrm{Al}$ Baitul Amien Elementary School (full day school) Jember.

\section{REFERENCES}

Amin, S. (2017). the Impact of Product Image To the Purchasing Decisions of Islamic Banking an Empirical Study of the Customer on Islamic Banking in. 2254-2266.

Arikunto, S. (1996) Prosedur Penelitian: Suatu Pendekatan praktek(Cetakan ke11). Jakarta: PT. Rineka Cipta.

Aritonang, K.T. (2005) "Hubungan Kompensasi Kerja, Disiplin Kerja Tenaga pengajar terhadap Kinerja Tenaga pengajar SMP Kristen BPK Penabur Jakarta". Jakarta: Jurnal Pendidikan Penabur, 4(4).

Daryatmi. (2005) Pengaruh Motivasi, Pengawasan, dan Budaya Kerja Terhadap Produktivitas Kerja Karyawan Perusahaan Daerah Bank Perkreditan Kredit Desa Kabupaten Karanganyar. Diakses pada http://eprints.ums.ac.id/125/ Daryatmi. pdf pada tanggal 30 Desember 2013.

Etykawaty, R. (2005) "PengaruhMotivasi dan Kedisiplinan terhadap Kinerja PetugasPemasyarakatan di Rumah Tahanan KelasI Surakarta”. Tesis. Surakarta: Universitas Muhammadiyah.

Ghozali, I. (2005) Aplikasi AnalisisMultivariatdengan Program SPSS. Semarang: Universitas Diponegoro.

Hoy, W.K, \& Miskel, C.G. (2001) Educational Administration: Theory Research and Practice (Sixth Edition). New York: McGrrawHill.

Julianti, L.M. (2010) "Pengaruh Budaya Kerja Terhadap Kinerja Karyawan Pada Pabrik Kelapa Sawit (PKS) Rambutan PTPN III(Persero). Skripsi Fakultas Ekonomi Universitas Sumatera Utara.

Kartono, K. (1995) Manajemen Industri. Bandung: Rajawali. Mangkunegara, AA. (2006) Evaluasi KinerjaSDM (Cet. $K e-10)$. Bandung: PT. Refika Aditema.

Margono, S. (2003) Metodologi Penelitian Pendidikan. Jakarta: PT. Rineka 
Cipta.Nitisemito, A.S. (1991) Manajemen Personalia.Jakarta: Ghalia.

Rivai, V. \& Basri, A.F.M. (2005) Performance Appraisal. Jakarta: PT. RajaGrafindo Persada.

Sastrohadiwiryo, B.S. (2003) Manajemen Tenaga Kerja Indonesia, Pendekatan Administratif dan Operasional. Jakarta:Bumi Aksara.

Schermenharn, J.R. (2003) Manajemen (EdisiBahasa Indonesia). Yogyakarta: PenerbitAndi.

Singarimbun, M. \& Effendi, S. (1990) MetodePenelitian Survai. Jakarta:
LP3ES.Triguno. (1995) Budaya Kerja. Jakarta:Gunung Agung.

Trisno, I. \& Suwarti, T. (2004) "Analisis Pengaruh Kompensasi dan Lingkungan kerja terhadap Kinerja Aparat Pemerintah (Studi Kasus Pada Dinas Perindustriandan Perdagangan KabupatenPati)”. Jurnal Ilmiah Telaah Manajemen,1(1).

Usman, M.U. (2003) Menjadi Guru Profesional.Bandung: PT. Remaja Rosdakarya. 